\title{
Determinants and Impact of Sovereign Credit Ratings
}

\section{Richard $\mathrm{C}$ antor and F rank Packer}

$n$ recent years, the demand for sovereign credit ratings- the risk assessments assigned by the credit rating agencies to the obligations of central governments- has increased dramatically. More governments with greater default risk and more companies domiciled in riskier host countries are borrowing in international bond markets. Although foreign government officials generally cooperate with the agencies, rating assignments that are lower than anticipated often prompt issuers to question the consistency and rationale of sovereign ratings. How clear are the criteria underlying sovereign ratings? Moreover, how much of an impact do ratings have on borrowing costs for sovereigns?

To explore these questions, we present the first systematic analysis of the determinants and impact of the sovereign credit ratings assigned by the two leading U.S. agencies, Moody's Investors Service and Standard and Poor's. ${ }^{1}$ Such an analysis has only recently become possible as a result of the rapid growth in sovereign rating assign- ments. The wealth of data now available allows us to estimate which quantitative indicators are weighed most heavily in the determination of ratings, to eval uate the pre dictive power of ratings in explaining a cross-section of sovereign bond yields, and to measure whether rating announcements directly affect market yields on the day of the announcement.

Our investigation suggests that, to a large extent, M oody's and Standard and Poor's rating assignments can be explained by a small number of well-defined criteria, which the two agencies appear to weigh similarly. We also find that the market-as gauged by sovereign debt yields - broadly shares the relative rankings of sovereign credit risks made by the two rating agencies. In addition, credit ratings appear to have some independent influence on yields over and above their correlation with other publicly available information. In particular, we find that rating announcements have immediate effects on market pricing for non-investment-grade issues. 


\section{What Are SOVEREIGn Ratings?}

Like other credit ratings, sovereign ratings are assessments of the relative likelihood that a borrower will default on its obligations. ${ }^{2}$ Governments generally seek credit ratings to ease their own access (and the access of other issuers domiciled within their borders) to international capital markets, where many investors, particularly U.S. investors, prefer rated securities over unrated securities of apparently similar credit risk.

In the past, governments tended to seek ratings on their foreign currency obligations exclusively, because foreign currency bonds were more likely than domestic currency offerings to be placed with international investors. In recent years, however, international investors have increased their demand for bonds issued in currencies other than traditional global currencies, leading more sovereigns to obtain domestic currency bond ratings as well. To date, however, foreign currency ratings - the focus of this article- remain the more prevalent and influential in the international bond markets.

Sovereign ratings are important not only because some of the largest issuers in the international capital markets are national governments, but also because these assessments affect the ratings assigned to borrowers of the same nationality. For example, agencies seldom, if ever,

\begin{tabular}{|c|c|c|}
\hline Interpretation & Moody's & Standard and Poor's \\
\hline \multicolumn{3}{|l|}{ IN VESTMENT-GRADE RATINGS } \\
\hline $\mathrm{H}$ ighest quality & Aaa & AAA \\
\hline High quality & $\begin{array}{l}\mathrm{Aal} \\
\mathrm{Aa2} \\
\mathrm{Aa3}\end{array}$ & $\begin{array}{l}A A+ \\
A A \\
A A-\end{array}$ \\
\hline Strong payment capacity & $\begin{array}{l}\text { A } 1 \\
\text { A2 } \\
\text { A3 }\end{array}$ & $\begin{array}{l}A+ \\
A \\
A-\end{array}$ \\
\hline $\begin{array}{l}\text { A dequate payment } \\
\text { capacity }\end{array}$ & $\begin{array}{l}\text { Baa1 } \\
\text { Baa2 } \\
\text { Baa3 }\end{array}$ & $\begin{array}{l}\text { BBB+ } \\
\text { BBB } \\
\text { BBB- }\end{array}$ \\
\hline \multicolumn{3}{|l|}{ SPECULATIVE-GRADE RATINGS } \\
\hline $\begin{array}{l}\text { Likely to fulfill obligations, } \\
\text { ongoing uncertainty }\end{array}$ & $\begin{array}{l}\mathrm{Ba} 1 \\
\mathrm{Ba} 2 \\
\mathrm{Ba} 3\end{array}$ & $\begin{array}{l}\text { BB+ } \\
\text { BB } \\
\text { BB- }\end{array}$ \\
\hline High-risk obligations & $\begin{array}{l}\text { B1 } \\
\text { B2 } \\
\text { B3 }\end{array}$ & $\begin{array}{l}\mathrm{B}+ \\
\mathrm{B} \\
\mathrm{B}-\end{array}$ \\
\hline
\end{tabular}

$\mathrm{N}$ ote: To date, the agencies have not assigned sovereign ratings bel ow B3/B-. assign a credit rating to a local municipality, provincial government, or private company that is higher than that of the issuer's home country.

Moody's and Standard and Poor's each currently rate more than fifty sovereigns. Although the agencies use

Table2

SOVEREIGN CREDIT RATINGS

As of September 29, 1995

\begin{tabular}{|c|c|c|}
\hline Country & Moody's Rating & $\begin{array}{c}\text { Standard and Poor's } \\
\text { Rating }\end{array}$ \\
\hline Argentina & B1 & BB- \\
\hline Australia & Aa2 & AA \\
\hline Austria & Aaa & AAA \\
\hline Belgium & Aal & $\mathrm{AA}+$ \\
\hline Bermuda & Aal & AA \\
\hline Brazil & B1 & $B+$ \\
\hline Canada & $\mathrm{A} a 2$ & $\mathrm{AA}+$ \\
\hline Chile & Baal & $A-$ \\
\hline China & A3 & BBB \\
\hline Colombia & Baa3 & BBB- \\
\hline Czech R epublic & Baal & $\mathrm{BBB}+$ \\
\hline Denmark & Aal & $\mathrm{AA}+$ \\
\hline Finland & $\mathrm{Aa} 2$ & $A A-$ \\
\hline France & A aa & AAA \\
\hline Germany & A aа & AAA \\
\hline Greece & Ваa3 & BBB- \\
\hline $\mathrm{H}$ ong $\mathrm{K}$ ong & A3 & $A$ \\
\hline Hungary & Bal & $\mathrm{BB}+$ \\
\hline Iceland & $\mathrm{A} 2$ & $A$ \\
\hline India & Ваa3 & $\mathrm{BB}+$ \\
\hline Indonesia & Baа3 & BBB \\
\hline Ireland & $\mathrm{Aa} 2$ & $\mathrm{AA}$ \\
\hline Italy & A 1 & $A A$ \\
\hline Japan & A aа & AAA \\
\hline K orea & A 1 & $A A-$ \\
\hline Luxembourg & A aa & AAA \\
\hline Malaysia & $\mathrm{A} 1$ & $A+$ \\
\hline Malta & A2 & $A$ \\
\hline M exico & $\mathrm{Ba} 2$ & BB \\
\hline $\mathrm{N}$ etherlands & Aaa & AAA \\
\hline $\mathrm{N}$ ew Zeal and & $\mathrm{A} a 2$ & $\mathrm{AA}$ \\
\hline N orway & Aal & $A A A$ \\
\hline Pakistan & $\mathrm{B} 1$ & $B+$ \\
\hline Philippines & $\mathrm{Ba} 2$ & BB \\
\hline Poland & Ваa3 & BB \\
\hline Portugal & $\mathrm{A} 1$ & $A A-$ \\
\hline Singapore & $\mathrm{Aa} 2$ & AAA \\
\hline Slovak Republic & Ваa3 & $\mathrm{BB}+$ \\
\hline South Africa & Ваa3 & BB \\
\hline Spain & $\mathrm{Aa} 2$ & $A A$ \\
\hline Sweden & $\mathrm{Aa3}$ & $\mathrm{AA}+$ \\
\hline Switzerland & A aa & AAA \\
\hline Taiwan & Aa3 & $\mathrm{AA}+$ \\
\hline Thailand & $\mathrm{A} 2$ & A \\
\hline Turkey & $\mathrm{Ba3}$ & $B+$ \\
\hline United K ingdom & Aaa & AAA \\
\hline United States & A aa & AAA \\
\hline Uruguay & Bal & $\mathrm{BB}+$ \\
\hline Venezuela & $\mathrm{Ba} 2$ & $B+$ \\
\hline
\end{tabular}

Sources: Moody's; Standard and Poor's. 
different symbols in assessing credit risk, every Moody's symbol has its counterpart in Standard and Poor's rating scale (Table 1). This correspondence allows us to compare the sovereign ratings assigned by the two agencies. Of the forty-nine countries rated by both Moody's and Standard and Poor's in September 1995, twenty-eight received the same rating from the two agencies, twelve were rated higher by Standard and Poor's, and nine were rated higher by M oody's (Table 2). W hen the agencies disagreed, their ratings in most cases differed by one notch on the scale, although for seven countries their ratings differed by two notches. (A rating notch is a one-level difference on a rating scale, such as the difference between $A 1$ and $A 2$ for Moody's or between A+ and A for Standard and Poor's.)

\section{Determin ants of Sovereign Ratings}

In their statements on rating criteria, Moody's and Standard and Poor's list numerous economic, social, and political factors that underlie their sovereign credit ratings (M oody's 1991; M oody's 1995; Standard and Poor's 1994). Identifying the relationship between their criteria and

I dentifying the relationship between [ the two

agencies'] criteria and actual ratings... is

difficult, in part because some of the criteria are

not quantifiable M oreover, theagencies provide

little guidance as to the relative weights they

assign each factor.

actual ratings, however, is difficult, in part because some of the criteria are not quantifiable. Moreover, the agencies provide little guidance as to the relative weights they assign each factor. Even for quantifiable factors, determining the relative weights assigned by M oody's and Standard and Poor's is difficult because the agencies rely on such a large number of criteria.

In the article's next section, we use regression anal- ysis to measure the relative significance of eight variables that are repeatedly cited in rating agency reports as determinants of sovereign ratings. ${ }^{3}$ As a first step, however, we describe these variables and identify the measures we use to represent them in our quantitative analysis (Table 3). We explain below the relationship between each variable and a country's ability and willingness to service its debt:

- Per capita income. The greater the potential tax base of the borrowing country, the greater the ability of a government to repay debt. This variable can al so serve as a proxy for the level of political stability and other important factors.

- GDP growth. A relatively high rate of economic growth suggests that a country's existing debt burden will become easier to service over time.

- Inflation. A high rate of inflation points to structural problems in the government's finances. W hen a government appears unable or unwilling to pay for current budgetary expenses through taxes or debt issuance, it must resort to inflationary money finance. Public dissatisfaction with inflation may in turn lead to political instability.

- Fiscal balance. A large federal deficit absorbs private domestic savings and suggests that a government lacks the ability or will to tax its citizenry to cover current expenses or to service its debt. ${ }^{4}$

- External balance. A large current account deficit indicates that the public and private sectors together rely heavily on funds from abroad. Current account deficits that persist result in growth in foreign indebtedness, which may become unsustai nable over time.

- External debt. A higher debt burden should correspond to a higher risk of default. The weight of the burden increases as a country's foreign currency debt rises relative to its foreign currency earnings (exports). ${ }^{5}$

- Economic development. Although level of development is al ready measured by our per capita income variable, the rating agencies appear to factor a threshold effect into the relationship between economic development and risk. That is, once countries reach a certain income or level of development, they may be less likely to default. ${ }^{6}$ We proxy for this minimum income or development level with a simple indicator variable noting whether or not a country is classified as industrialized by the International M onetary Fund. 
Table3

DESCRIPTION OF VARIABLES

\begin{tabular}{|c|c|c|c|}
\hline Variable $\mathrm{N}$ ame & Definition & Unit of M easurement ${ }^{a}$ & Data Sources \\
\hline \multicolumn{4}{|l|}{ D eterminants of Sovereign R atings } \\
\hline Per capita income & GN P per capita in 1994 & Thousands of dollars & $\begin{array}{l}\text { World Bank, M oody's, FR BNY } \\
\text { estimates }\end{array}$ \\
\hline GDP growth & $\begin{array}{l}\text { Average annual real GDP growth on a } \\
\text { year-over-year basis, 1991-94 }\end{array}$ & Percent & $\begin{array}{l}\text { World Bank, M oody's, FR BNY } \\
\text { estimates }\end{array}$ \\
\hline Inflation & $\begin{array}{l}\text { Average annual consumer price inflation } \\
\text { rate, 1992-94 }\end{array}$ & Percent & $\begin{array}{l}\text { W orld Bank, M oody's, FRBNY } \\
\text { estimates }\end{array}$ \\
\hline Fiscal balance & $\begin{array}{l}\text { A verage annual central government budget } \\
\text { surplus relative to GDP, 1992-94 }\end{array}$ & Percent & $\begin{array}{l}\text { W orld Bank, M oody's, IM F, FRBN Y } \\
\text { estimates }\end{array}$ \\
\hline External balance & $\begin{array}{l}\text { A verage annual current account surplus } \\
\text { relative to GDP, 1992-94 }\end{array}$ & Percent & $\begin{array}{l}\text { World Bank, M oody's, FRBN Y } \\
\text { estimates }\end{array}$ \\
\hline External debt & $\begin{array}{l}\text { Foreign currency debt relative to exports, } \\
1994\end{array}$ & Percent & $\begin{array}{l}\text { W orld Bank, M oody's, FR BNY } \\
\text { estimates }\end{array}$ \\
\hline Indicator for economic devel opment & $\begin{array}{l}\text { IM F classification as an industrialized } \\
\text { country as of September } 1995\end{array}$ & $\begin{array}{l}\text { Indicator variable: } 1 \text { = industrialized; } \\
0=\text { not industrialized }\end{array}$ & IMF \\
\hline Indicator for default history & $\begin{array}{l}\text { Default on foreign currency debt } \\
\text { since } 1970\end{array}$ & $\begin{array}{l}\text { Indicator variable: } 1 \text { = default; } \\
0=\text { no default }\end{array}$ & $S \& P$ \\
\hline \multicolumn{4}{|l|}{ Other Variables } \\
\hline M oody's, S\&P, or average ratings & $\begin{array}{l}\text { Ratings assigned as of September } 29, \\
1995, \text { by M oody's or S\&P, or the average } \\
\text { of the two agencies' ratings }\end{array}$ & $\begin{array}{l}\mathrm{B} 1(\mathrm{~B}+)=3 ; \mathrm{Ba} 3(\mathrm{BB}-)=4 ; \\
\operatorname{Ba} 2(\mathrm{BB})=5 ; \ldots \mathrm{Aaa}(\mathrm{AAA})=16\end{array}$ & M oody's, S\&P \\
\hline Spreads & $\begin{array}{l}\text { Sovereign bond spreads over Treasuries, } \\
\text { adjusted to five-year maturities }\end{array}$ & Basis points & $\begin{array}{l}\text { Bloomberg L.P., Salomon Brothers, } \\
\text { J.P. M organ, FR BNY estimates }\end{array}$ \\
\hline
\end{tabular}

N ote: $S \& P=$ Standard and Poor's; FR BN Y = Federal R eserve Bank of $N$ ew York; IM F= International M onetary Fund.

${ }^{a}$ In the regression analysis, per capita income, inflation, and spreads are transformed to natural logarithms.

${ }^{b}$ For example, the spread on a three-year maturity Baa/BBB sovereign bond is adjusted to a five-year maturity by subtracting the difference between the average spreads on three-year and five-year Baa/B BB corporate bonds as reported by Bloomberg L.P. on September 29, 1995.

- D efault history. Other things being equal, a country that has defaulted on debt in the recent past is widely perceived as a high credit risk. Both theoretical considerations of the role of reputation in sovereign debt (Eaton 1996) and related empirical evidence indicate that defaulting sovereigns suffer a severe decline in their standing with creditors (Ozler 1991). We factor in credit reputation by using an indicator variable that notes whether or not a country has defaulted on its international bank debt since 1970.

\section{QUANTIFYING THE RELATIONSHIP BETWEEN RATINGSAND THEIR DETERMINANTS}

In this section, we assess the individual and collective significance of our eight variables in determining the September 29, 1995, ratings of the forty-nine countries listed in Table 2. The sample statistics, broken out by broad letter category, show that five of the eight variables are directly correlated with the ratings assigned by Moody's and Standard and Poor's (Table 4). In particular, a high per capita income appears to be closely related to high ratings: among the nine countries assigned top ratings by Moody's and the eleven given Standard and Poor's highest ratings, median per capita income is just under $\$ 24,000$. Lower inflation and lower external debt are also consistently related to higher ratings. A high level of economic devel-

A high per capita income appears to be closely related to high ratings. ... . L ower inflation and low er external debt arealso consistently related to higher ratings.

opment, as measured by the indicator for industrialization, greatly increases the likelihood of a rating of $A a / A A$. As a negative factor, any history of default limits a sovereign's ratings to $\mathrm{B}$ aa/BBB or bel ow.

Three factors-GDP growth, fiscal balance, and external balance- lack a clear bivariate relation to ratings. Ratings may lack a simple relation to GDP growth because 
many developing economies tend to grow faster than mature economies. M ore surprising, however, is the lack of a clear correlation between ratings and fiscal and external balances. This finding may reflect endogeneity in both fiscal policy and international capital flows: countries trying to improve their credit standings may opt for more conservative fiscal policies, and the supply of international capital may be restricted for some low-rated countries.

Because some of the eight variables are mutually correlated, we estimate a multiple regression to quantify their combined explanatory power and to sort out their individual contributions to the determination of ratings. Like most analysts who transform bond ratings into data for regression analysis (beginning with Horrigan 1966 and continuing through Billet 1996), we assign numerical values to the Moody's and Standard and Poor's ratings as follows: $B 3 / B-=1, B 2 / B=2$, and so on through $A$ aa/ $A A A=16$. W hen we need a measure of a country's average rating, we take the mean of the two numerical values representing Moody's and Standard and Poor's ratings for that country. Our regressions relate the numerical equival ents of Moody's and Standard and Poor's ratings to the eight explanatory variables through ordinary least squares. ${ }^{7}$

The model's ability to predict large differences in ratings is impressive. The first column of Table 5 shows

Themode's ability to predict I arge differences in ratings is impressive. . . A regression of the average of M oody's and Standard and P oor's ratings against our set of eight variables explains morethan 90 percent of the sample variation.

that a regression of the average of Moody's and Standard and Poor's ratings against our set of eight variables explains more than 90 percent of the sample variation and yields a residual standard error of about 1.2 rating notches. $\mathrm{N}$ ote that although the model's explanatory power is impressive,

\begin{tabular}{|c|c|c|c|c|c|c|c|}
\hline & Agency & A aa/AAA & $\mathrm{A} a / \mathrm{AA}$ & $\mathrm{A} / \mathrm{A}$ & Baa/BBB & $\mathrm{Ba} / \mathrm{BB}$ & $\mathrm{B} / \mathrm{B}$ \\
\hline $\begin{array}{l}\text { MEDIANS } \\
\text { Per capita income }\end{array}$ & $\begin{array}{l}\text { Moody's } \\
\text { S\&P }\end{array}$ & $\begin{array}{l}23.56 \\
23.56\end{array}$ & $\begin{array}{l}19.96 \\
18.40\end{array}$ & $\begin{array}{l}8.22 \\
5.77\end{array}$ & $\begin{array}{l}2.47 \\
1.62\end{array}$ & $\begin{array}{l}3.30 \\
3.01\end{array}$ & $\begin{array}{l}3.37 \\
2.61\end{array}$ \\
\hline GDP growth & $\begin{array}{l}\text { Moody's } \\
\text { S\&P }\end{array}$ & $\begin{array}{l}1.27 \\
1.52\end{array}$ & $\begin{array}{l}2.47 \\
2.33\end{array}$ & $\begin{array}{l}5.87 \\
6.49\end{array}$ & $\begin{array}{l}4.07 \\
5.07\end{array}$ & $\begin{array}{l}2.28 \\
2.31\end{array}$ & $\begin{array}{l}4.30 \\
2.84\end{array}$ \\
\hline Inflation & $\begin{array}{l}\text { Moody's } \\
\text { S\&P }\end{array}$ & $\begin{array}{l}2.86 \\
2.74\end{array}$ & $\begin{array}{l}2.29 \\
2.64\end{array}$ & $\begin{array}{l}4.56 \\
4.18\end{array}$ & $\begin{array}{r}13.73 \\
14.3\end{array}$ & $\begin{array}{l}32.44 \\
13.23\end{array}$ & $\begin{array}{l}13.23 \\
62.13\end{array}$ \\
\hline Fiscal balance & $\begin{array}{l}\text { Moody's } \\
\text { S\&P }\end{array}$ & $\begin{array}{l}-2.67 \\
-2.29\end{array}$ & $\begin{array}{l}-2.28 \\
-3.17\end{array}$ & $\begin{array}{r}-1.03 \\
1.37\end{array}$ & $\begin{array}{r}-3.50 \\
0.15\end{array}$ & $\begin{array}{l}-2.50 \\
-3.50\end{array}$ & $\begin{array}{l}-1.75 \\
-4.03\end{array}$ \\
\hline External balance & $\begin{array}{l}\text { Moody's } \\
\text { S\&P }\end{array}$ & $\begin{array}{l}0.90 \\
3.10\end{array}$ & $\begin{array}{r}2.10 \\
-0.73\end{array}$ & $\begin{array}{l}-2.48 \\
-3.68\end{array}$ & $\begin{array}{l}-2.10 \\
-2.10\end{array}$ & $\begin{array}{l}-2.74 \\
-3.35\end{array}$ & $\begin{array}{l}-3.35 \\
-1.05\end{array}$ \\
\hline External debt & $\begin{array}{l}\text { Moody's } \\
\text { S\&P }\end{array}$ & $\begin{array}{l}76.5 \\
76.5\end{array}$ & $\begin{array}{r}102.5 \\
97.2\end{array}$ & $\begin{array}{l}70.4 \\
61.7\end{array}$ & $\begin{array}{l}157.2 \\
157.2\end{array}$ & $\begin{array}{l}220.2 \\
189.7\end{array}$ & $\begin{array}{l}291.6 \\
231.6\end{array}$ \\
\hline Spread & $\begin{array}{l}\text { Moody's } \\
\text { S\&P }\end{array}$ & $\begin{array}{l}0.32 \\
0.29\end{array}$ & $\begin{array}{l}0.34 \\
0.40\end{array}$ & $\begin{array}{l}0.61 \\
0.59\end{array}$ & $\begin{array}{l}1.58 \\
1.14\end{array}$ & $\begin{array}{l}3.40 \\
2.58\end{array}$ & $\begin{array}{l}4.45 \\
3.68\end{array}$ \\
\hline $\begin{array}{l}\text { FREQUEN CIES } \\
\text { N umber rated }\end{array}$ & $\begin{array}{c}\text { Moody's } \\
\text { S\&P }\end{array}$ & $\begin{array}{r}9 \\
11\end{array}$ & $\begin{array}{l}13 \\
14\end{array}$ & $\begin{array}{l}9 \\
6\end{array}$ & $\begin{array}{l}9 \\
5\end{array}$ & $\begin{array}{l}6 \\
9\end{array}$ & $\begin{array}{l}3 \\
4\end{array}$ \\
\hline $\begin{array}{l}\text { Indicator for economic } \\
\text { devel opment }\end{array}$ & $\begin{array}{l}\text { Moody's } \\
\text { S\&P }\end{array}$ & $\begin{array}{r}9 \\
10\end{array}$ & $\begin{array}{l}10 \\
11\end{array}$ & $\begin{array}{l}3 \\
1\end{array}$ & $\begin{array}{l}1 \\
1\end{array}$ & $\begin{array}{l}0 \\
0\end{array}$ & $\begin{array}{l}0 \\
0\end{array}$ \\
\hline $\begin{array}{l}\text { Indicator for default } \\
\text { history }\end{array}$ & $\begin{array}{c}\text { Moody's } \\
\text { S\&P }\end{array}$ & $\begin{array}{l}0 \\
0\end{array}$ & $\begin{array}{l}0 \\
0\end{array}$ & $\begin{array}{l}0 \\
0\end{array}$ & $\begin{array}{l}2 \\
0\end{array}$ & $\begin{array}{l}5 \\
6\end{array}$ & $\begin{array}{l}2 \\
3\end{array}$ \\
\hline
\end{tabular}

Sources: Moody's; Standard and Poor's; W orld Bank; International M onetary Fund; Bloomberg L.P.; J.P. M organ; Federal Reserve Bank of N ew York estimates. 
the regression achieves its high $\mathrm{R}$-squared through its ability to predict large rating differences. For example, the specification predicts that Germany's rating (Aaa/AAA) will be much higher than Uruguay's $(B a 1 / B B+)$. The model naturally has little to say about small rating differences-for example, why Mexico is rated Ba2/BB and South A frica is rated Baa3/BB. These differences, while modest, can cause great controversy in financial markets.

The regression does not yield any prediction errors that exceed three notches, and errors that exceed two notches occur in the case of only four countries. A nother way of mea suring the accuracy of this specification is to compare predicted ratings rounded off to the nearest broad letter rating with actual broad letter ratings. The average rating regression predicts these broad letter ratings with about 70 percent accuracy, a slightly higher accuracy rate than that found in the literature quantifying the determinants of corporate ratings (see, for example, Ederington [1985]).

Of the individual coefficients, per capita income, GDP growth, inflation, external debt, and the indicator variables for economic development and default history all have the anticipated signs and are statistically significant. The coefficients on both the fiscal and external bal ances are statistically insignificant and of the unexpected sign. As mentioned earlier, in many cases the market forces poor credit risks into apparently strong fiscal and external balance positions, diminishing the significance of fiscal and external balances as explanatory variables. Therefore, although the agencies may assign substantial weight to these variables in determining specific rating assignments, no systematic relationship between these variables and ratings is evident in our sample.

Table 5

Determinants of Sovereign Credit Ratings

Dependent Variable

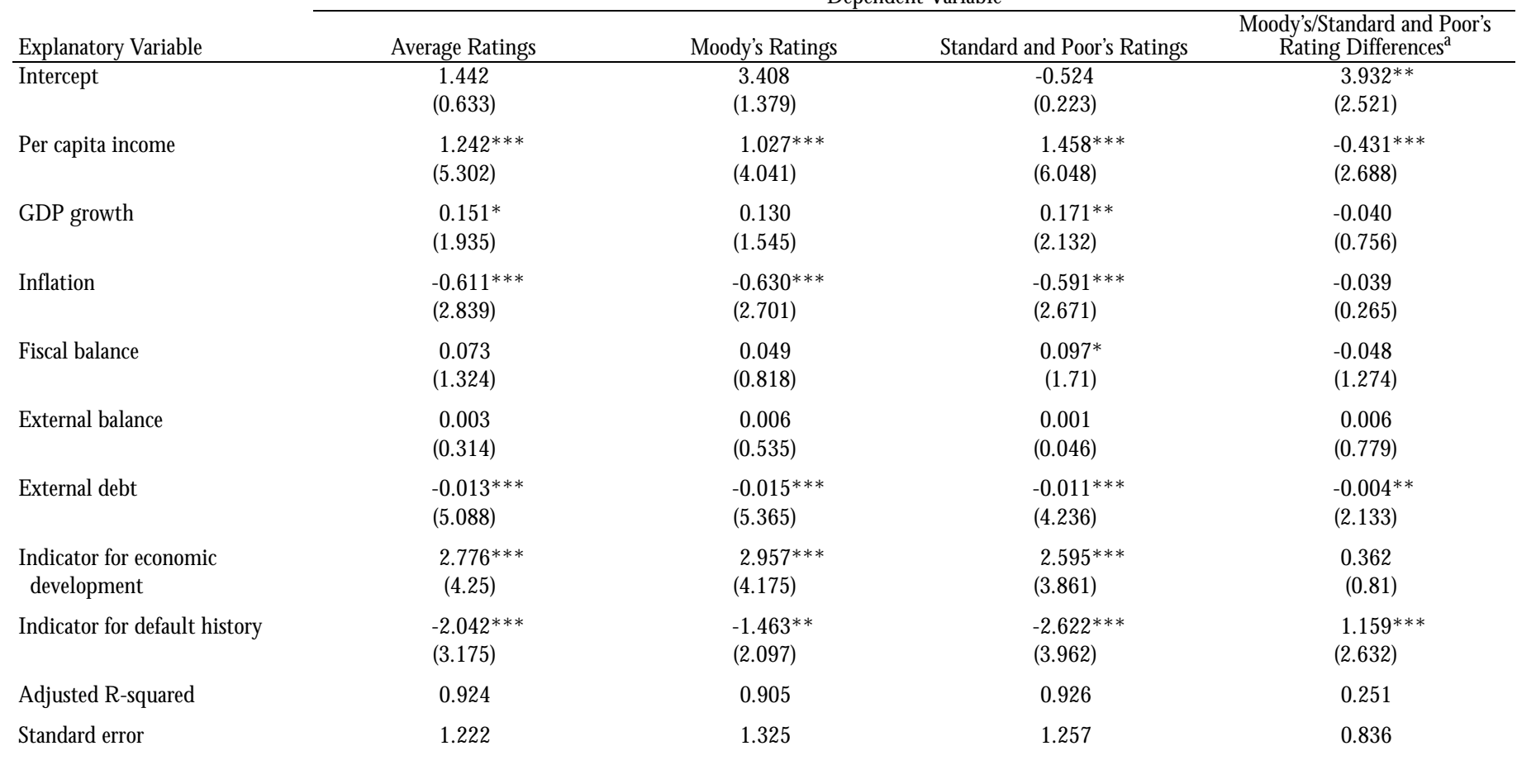

Sources: M oody's; Standard and Poor's; W orld Bank; International M onetary Fund; Bloomberg L.P.; Sal omon Brothers; J.P. M organ; Federal R eserve Bank of N ew York estimates.

N otes: The sample size is forty-nine. A bsolute t-statistics are in parentheses.

TT he number of rating notches by which M oody's ratings exceed Standard and Poor's.

* Significant at the 10 percent level.

** Significant at the 5 percent level.

*** Significant at the 1 percent level. 
Quantitative models cannot explain all variations in ratings across countries: as the agencies often state, qualitative social and political considerations are also important determinants. For example, the average rating regression predicts $\mathrm{H}$ ong $\mathrm{K}$ ong's rating to be al most three notches higher than its actual rating. Of course, $\mathrm{H}$ ong K ong's actual rating reflects the risks inherent in its 1997 incorporation into China. If the regression had failed to identify $\mathrm{H}$ ong $\mathrm{K}$ ong as an outlier, we would suspect it was misspecified and/or overfitted.

Our statistical results suggest that Moody's and Standard and Poor's broadly share the same rating criteria, although they weight some variables differently (Table 5, columns 2 and 3). The general similarity in criteria should not be surprising given that the agencies agree on individual ratings more than half the time and most of their disagreements are small in magnitude. The fourth column of Table 5 reports a regression of rating differences (M oody's less Standard and Poor's ratings) against these variables. Focusing only on the statistically significant coefficients, we find that Moody's appears to place more weight on external debt and less weight on default history as negative factors than does Standard and Poor's. Moreover, M oody's places less weight on per capita income as a positive factor. ${ }^{8}$

In addition to the relationship between a country's economic indicators and its sovereign ratings, the effect of ratings on yields is of interest to market practitioners. Although ratings are clearly correlated with yields, it is far from obvious that ratings actually influence yields. The observed correlation could be coincidental if investors and rating agencies share the same interpretation of a body of public information pertaining to sovereign risks. In the next section, we investigate the degree to which ratings explain yields. After examining a cross-section of yields, ratings, and other potential explanatory factors at one point in time, we examine the movement of yields when rating announcements occur.

\section{The CRoss-Sectional ReLATION SH IP BETWEEN RATINGS AND YIELDS}

In the fall of 1995, thirty-five countries rated by both M oody's and Standard and Poor's had actively traded Euro- dollar bonds. For each country, we identified its most liquid Eurodollar bond and obtained its spread over U.S. Treasuries as reported by Bloomberg L.P. on September 29, 1995. A regression of the log of these countries' bond spreads against their average ratings shows that ratings have considerable power to explain sovereign yields (Table 6, column 1). ${ }^{9}$ The single rating variable explains 92 percent of the variation in spreads, with a standard error of 20 basis points. We also tried a number of alternative regressions based on Moody's and Standard and Poor's ratings, but none significantly improved the fit. ${ }^{10}$

Sovereign yields tend to rise as ratings decline. This pattern is evident in Chart 1, which plots the observed sovereign bond spreads as well as the predicted values from the average rating specification. An additional plot of average corporate spreads at each rating shows that

Table6

DO RATINGSAdD TO PUBLIC InFORMATION?

Intercept

Average ratings

\begin{tabular}{ccc}
\multicolumn{3}{c}{ Dependent Variable: Log (Spreads) } \\
\hline$(1)$ & $(2)$ & $(3)$ \\
\hline $2.105^{* * *}$ & 0.466 & 0.074 \\
$(16.148)$ & $(0.345)$ & $(0.071)$
\end{tabular}

Per capita income

$-0.221 * * *$

(19.715)

$-0.218 * * *$

$(4.276)$

Per capita income

$-0.144$

0.226

GDP growth

(0.927)

(1.523)

Inflation

$-0.004$

0.029

(0.142)

(1.227)

Intion

0.108

(1.393)

$-0.004$

Fiscal balance

$-0.037$

(1.557)

External balance

$-0.038$

(1.29)

External debt

Indicator for economic

development

$0.003 * * *$

(2.651)

Indicator for default

$-0.723 * *$

(2.059)

(0.068)

history

$0.612 * * *$

(2.577)

$-0.02$

(1.045)

Adjusted R-squared

0.919

0.857

$-0.023$

(1.008)

Standard error

0.294

0.392

0.000

$(0.095)$

$-0.38$

(1.341)

0.085

(0.385)

0.914

0.304

Sources: M oody's; Standard and Poor's; W orld Bank; International M onetary Fund; Bloomberg L.P.; Salomon Brothers; J.P. M organ; Federal R eserve Bank of $N$ ew York estimates.

$\mathrm{N}$ otes: The sample size is thirty-five. A bsolute t-statistics are in parentheses.

* Significant at the 10 percent level.

** Significant at the 5 percent level.

*** Significant at the 1 percent level. 
sovereign bonds rated below $A$ tend to be associated with higher spreads than comparably rated U.S. corporate securities. One interpretation of this finding is that although financial markets generally agree with the agencies' relative ranking of sovereign credits, they are more pessimistic than Moody's and Standard and Poor's about sovereign credit risks bel ow the A level.

O ur findings suggest that the ability of ratings to explain relative spreads cannot be wholly attributed to a mutual correlation with standard sovereign risk indicators. A regression of spreads against the eight variables used to predict credit ratings explains 86 percent of the sample variation (Table 6 , column 2). Because ratings alone explain 92 percent of the variation, ratings appear to provide additional information beyond that contained in the standard macroeconomic country statistics incorporated in market yields.

In addition, ratings effectively summarize the information contained in macroeconomic indicators. ${ }^{11}$ The third column in Table 6 presents a regression of spreads against average ratings and all the determinants of average ratings collectively. In this specification, the average rating coefficient is virtually unchanged from its coefficient in the

Chart 1

Sovereign Bond Spreads by Credit Rat ing As of September 29, 1995

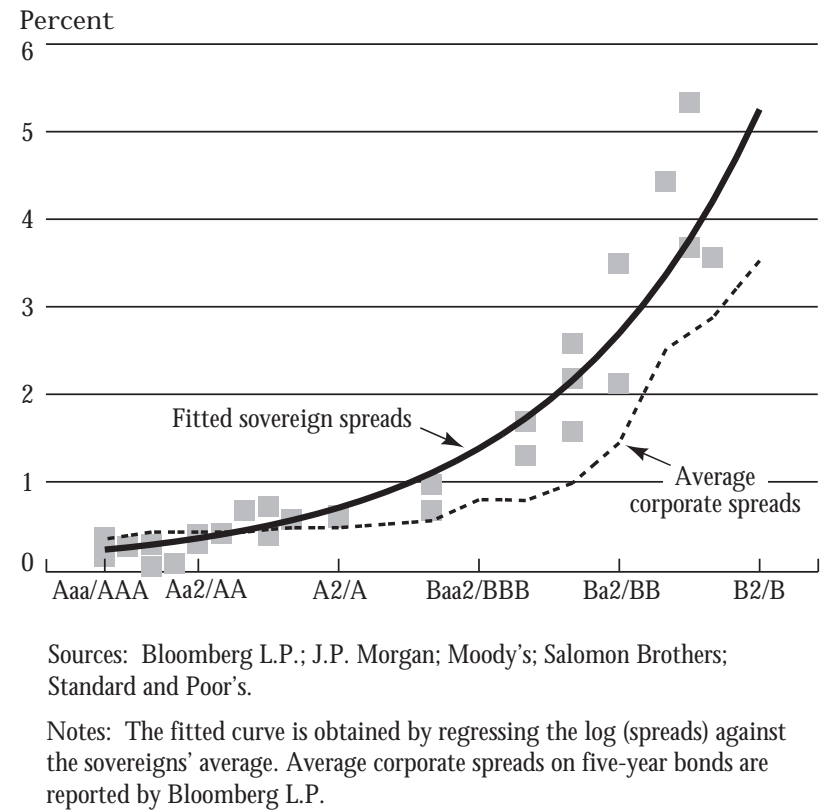

first column of Table 6, and the other variables are collectively and individually insignificant. Moreover, the adjusted R-squared in the third specification is lower than

Our findings suggest that the ability of

ratings to explain relative spreads cannot be

wholly attributed to a mutual correlation with standard sovereign risk indicators.

in the first, implying that the macroeconomic indicators do not add any statistically significant explanatory power to the average rating model.

The results of our cross-sectional tests agree in part with those obtained from similar tests of the information content of corporate bond ratings (Ederington, Yawitz, and Roberts 1987) and municipal bond ratings (M oon and Stotsky 1993). Like the authors of these studies, we conclude that ratings may contain information not available in other public sources. Unlike these authors, however, we find that standard indicators of default risk provide no useful information for predicting yields over and above their correlations with ratings.

\section{THE IMPACT OF RATING AN N OUN CEMENTS ON DOLLAR BOND SPREADS}

We next investigate how dollar bond spreads respond to the agencies' announcements of changes in their sovereign risk assessments. Certainly, many market participants are aware of specific instances in which rating announcements led to a change in existing spreads. Table 7 presents four recent examples of large moves in spread that occurred around the time of widely reported rating changes.

of course, we do not expect the market impact of rating changes to be this large on average, in part because many rating changes are anticipated by the market. To move beyond anecdotal evidence of the impact of rating announcements, we conduct an event study to measure the effects of a large sample of rating announcements on yield 
spreads. Similar event studies have been undertaken to measure the impact of rating announcements on U.S. corporate bond and stock returns. In the most recent and most thorough of these studies, $\mathrm{H}$ and, $\mathrm{H}$ olthausen, and Leftwich (1992) show that rating announcements directly affect corporate securities prices, al though market anticipation often mutes the average effects. ${ }^{12}$

To construct our sample, we attempt to identify every announcement made by Moody's or Standard and Poor's between 1987 and 1994 that indicated a change in sovereign risk assessment for countries with dollar bonds that traded publicly during that period. Altogether, we gather a sample of seventy-nine such announcements in eighteen countries. ${ }^{13}$ Thirty-nine of the announcements report actual rating changes-fourteen upgrades and twenty-five downgrades. The other forty announcements are "outlook" (Standard and Poor's term) or "watchlist" (M oody's term) changes: ${ }^{14}$ twenty-three ratings were put on review for possible upgrade and seventeen for possible downgrade.

We then examine the average movement in credit spreads around the time of negative and positive announcements. Chart 2 shows the movements in relative yield spreads-yield spreads divided by the appropriate U.S. Treasury rate- thirty days before and twenty days after rating announcements. We focus on relative spreads because studies such as Lamy and Thompson (1988) suggest that they are more stable than absolute spreads and fluctuate less with the general level of interest rates.

Agency announcements of a change in sovereign risk assessments appear to be preceded by a similar change in the market's assessment of sovereign risk. During the twenty-nine days preceding negative rating announcements, relative spreads rise 3.3 percentage points on an average cumulative basis. Similarly, relative spreads fall

Chart 2

Trends in Sovereign Bond Spreads before and after Rating Announcements

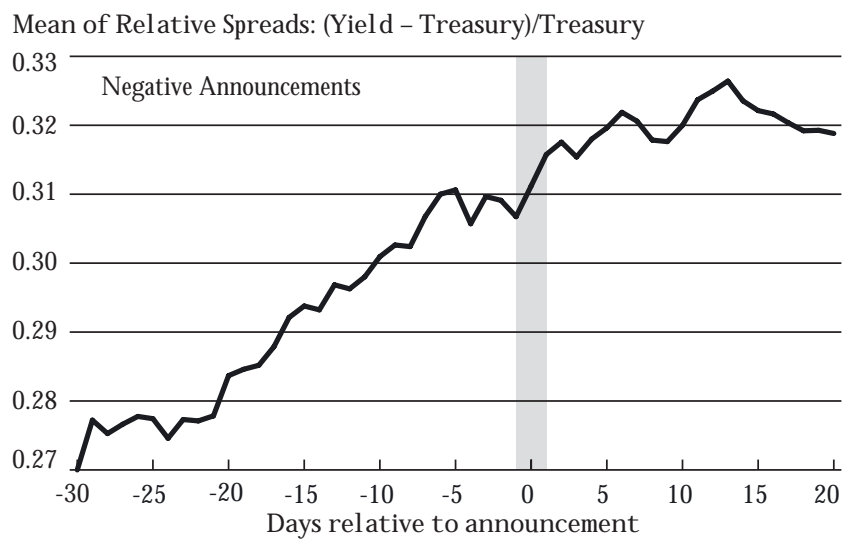

Mean of Rel at ive Spreads: (Y iel d -Treasury)/Treasury

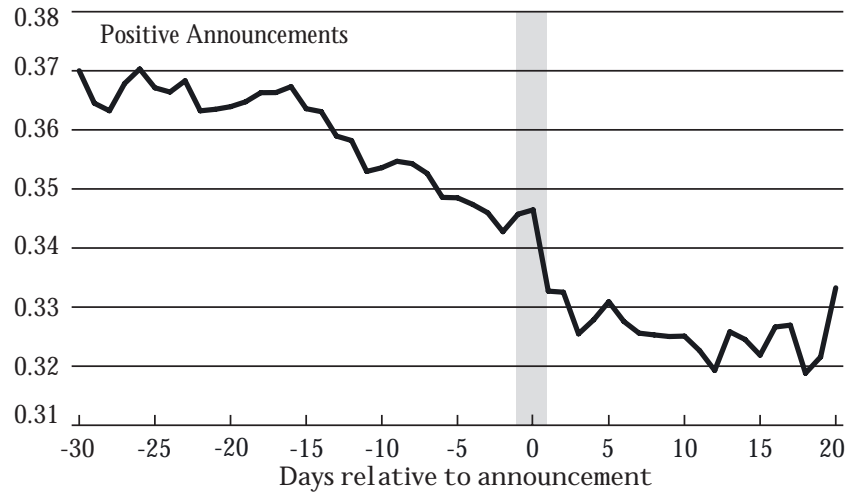

Sources: Bloomberg L.P.; J.P. M organ; Federal Reserve Bank of N ew Y ork estimates.

N otes: The shaded areas in each panel highlight the period during which announcements occur. Spreads are cal culated as the yield to maturity of the benchmark dollar bond for each sovereign minus the yield of the U.S. Treasury of comparable maturity. The charts are based on forty-eight negative and thirty-one positive announcements.

Table 7

LaRge Movementsin Sovereign Bond Spreadsat the Time of Rating Ann ouncements

\begin{tabular}{|c|c|c|c|c|}
\hline Country & Date & Agency & Old Rating $=>N$ ew Rating & $\begin{array}{c}\text { Old Spread => N ew Spread } \\
\text { (In Basis Points) }\end{array}$ \\
\hline \multicolumn{5}{|c|}{ DOWNGRADES } \\
\hline Turkey & March 22, 1994 & Standard and Poor's & $B B B-=>B B$ & $371=>408$ \\
\hline Brazil & N ovember 30, 1994 & Moody's & $B 2=>B 1$ & $410=>326$ \\
\hline Venezuela & August 7, 1991 & Moody's & $\mathrm{Ba3}=>\mathrm{Ba} 1$ & $274=>237$ \\
\hline
\end{tabular}

Sources: M oody's; Standard and Poor's; Bloomberg L.P.; J.P. M organ.

$N$ ote: The old (new) spread is measured at the end of the trading day before (after) the announcement day. 
about 2.0 percentage points during the twenty-nine days preceding positive rating announcements. The trend movement in spreads disappears approximately six days before negative announcements and flattens shortly before positive announcements. Following the announcements, a small drift in spread is still discernible for both upgrades and downgrades.

Do rating announcements themselves have an impact on the market's perception of sovereign risk? To

To move beyond anecdotal evidence of the impact of rating announcements, we conduct an event study to measure the effects of a large sample of rating announcements on yiedd spreads.

capture the immediate effect of announcements, we look at a two-day window - the day of and the day after the announcement-because we do not know if the announcements occurred before or after the daily close of the bond market. Within this window, relative spreads rose 0.9 percentage points for negative announcements and fell 1.3 percentage points for positive announce- ments. Although these movements are smaller in absolute terms than the cumulative movements over the preceding twenty-nine days, they represent a considerably larger change on a daily basis. ${ }^{15}$ These results suggest that rating announcements themselves may cause a change in the market's assessment of sovereign risk.

Statistical analysis confirms that for the full sample of seventy-nine events, the impact of rating announcements on dollar bond spreads is highly significant. ${ }^{16}$ Table 8 reports the mean and median changes in the log of the relative spreads during the announcement window for the full sample as well as for four pairs of rating announcement categories: positive versus negative announcements, rating change versus outlook/ watchlist change announcements, Moody's versus Standard and Poor's announcements, and announcements concerning investment-grade sovereigns versus announcements concerning speculativegrade sovereigns. ${ }^{17}$ Because positive rating announcements should be associated with negative changes in spread, we multiply the changes in the log of the relative spread by -1 when rating announcements are positive. This adjustment allows us to interpret all positive changes in spread, regardless of the announcement, as being in the direction expected given the announcement.

Roughly 63 percent of the full sample of rating announcements are associated with changes in spread in the expected direction during the announcement period,

Table 8

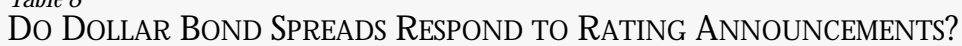

Changes in Relative Spreads at the Time of Rating Announcements

All announcements
Positive announcements
N egative announcements
Rating changes
Outlook/watchlist changes
Moody's announcements
Standard and Poor's
announcements
Investment grade
Speculative grade

\begin{tabular}{cc} 
N umber of Observations & M ean Change \\
\hline 79 & 0.025 \\
31 & 0.027 \\
48 & 0.023 \\
39 & 0.035 \\
40 & 0.015 \\
29 & 0.048 \\
50 & 0.011 \\
52 & 0.018 \\
27 & 0.038
\end{tabular}

N otes: Relative spreads are measured in logs, that is, In [(yield - Treasury)/Treasury)]. Changes in the logs of relative spreads are multiplied by - 1 in the case of positive announcements. Significance for the percent positive statistic is based on a binomial test of the hypothesis that the underlying probability is greater than 50 percent.

* Significant at the 10 percent level.

** Significant at the 5 percent level.

*** Significant at the 1 percent level. 
with a mean change in the log of relative spreads of about 2.5 percent. This finding is consistent with the announcement effect for U.S. corporate bonds documented by $\mathrm{H}$ and, $\mathrm{H}$ olthausen, and Leftwich (1992). In fact, the share of responses in the expected direction is consistently above 50 percent regardless of the category of rating announcement. Moreover, the mean changes are always positive regardless of category.

Tests of statistical significance do suggest some differences between categories, however. Most strikingly, by both the mean change and percent positive measures, rating announcements have a highly significant impact on speculative-grade sovereigns but a statistically insignificant effect on investment-grade sovereigns. (By contrast, $\mathrm{H}$ and, $\mathrm{H}$ olthausen, and Leftwich find that rating announcements have a significant impact on both investment-grade and speculative-grade corporate bonds.) Table 8 al so reveals that the mean change statistics are not signif- icant for negative announcements, ${ }^{18}$ outlook/watchlist announcements, and Standard and Poor's announcements, although the percent positive statistics are significant for those categories. Because the statistical inferences for certain categories are ambiguous, and because the various categories overlap, we employ a multiple regression to sort out which categories of rating announcements imply meaningfully different effects on spreads.

We run a regression of the change in relative spreads against four indicator variables that take on the value 1 (or 0 ) depending on whether (or not) the rating announcements involve actual rating changes, positive events, Moody's decisions, or speculativegrade sovereigns (Table 9, column 1). As might be expected from Table 8, the estimated coefficients are all positive. Only the coefficients on the M oody's and speculativegrade indicator variables, however, are statistically significant. ${ }^{19}$ Thus, the multiple regression indicates that the immediate impact of

Tableg

W HAT DETERMINES REACTIONSTO RATIN G AN N OUN CEMENTS?

W eighted Regressions of Changes in Relative Spreads on Explanatory Factors

Constant

Positive announcements

Rating changes

M oody's announcements

Speculative grade

Change in relative spreads from day -60 to day -1

Rating gap indicator

Other rating announcements from day -60 to day -1

Adjusted R-squared

\begin{tabular}{cc}
$(1)$ & $(2)$ \\
\hline-0.02 & -0.01 \\
$(0.97)$ & $(0.39)$
\end{tabular}

0.01

(0.72)

0.02

(1.04)

0.03*

(1.8)

$0.03 * *$

(1.98)

0.05

$\begin{array}{r}-0.05 \\ -\quad 0.98 \\ \hline\end{array}$

$-$

(0.39)

0.01
$(0.53)$

0.01

(0.81)

0.03

(1.61)

$0.03^{* *}$

(2.25)

$-0.05$

(0.98)

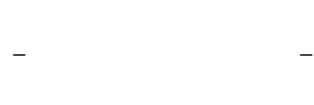

0.03
(3)

$-0.03^{*}$
$(1.73)$

0.00

(0.11)

0.01

(0.58)

$0.03^{*}$

(1.92)

$0.03 * *$

(2.24)

$-$

$0.04 * *$

(2.34)

0.10
(4)

(1.11)

0.01

(1.02)

0.00

(0.13)

0.02

(1.53)

0.03*

(1.67)

$\begin{array}{ll}- & -0.06\end{array}$

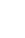

$0.05 * *$

(2.42)

0.11
(5)

$-0.02$

0.01

(0.34)

$-0.01$

(0.37)

0.02

(1.51)

$0.03^{* *}$

(2.33)

$-0.06$

(1.1)

0.03*

(1.7)

$0.05^{* *}$

(2.15)

0.12

N otes: A bsolute t-statistics are in parentheses. Relative spreads are measured in logs, that is, In [(yield - Treasury)/Treasury]. Changes in the logs of relative spreads are multiplied by -1 in the case of positive announcements. Variables are weighted in the regressions by the inverse of the standard deviation of daily change in the log of relative spreads from day - 100 to day -10 .

* Significant at the 10 percent level.

** Significant at the 5 percent level. 
an announcement on yield spreads is greater if the announcement is made by M oody's or if it is related to speculative-grade credit. By contrast, the impact of announcements does not appear to rely on the distinction between rating changes and outlook/watchlist changes or the distinction between positive and negative announcements.

We have established the impact of certain rating announcements on dollar bond spreads, but a second question arises: to what extent does anticipation by the market dilute the impact of these announcements? The presence of many well-anticipated events in our dataset could obscure highly significant responses to unanticipated announcements-including, perhaps, announcements by Standard and Poor's or announcements concerning investment-grade sovereigns. 20

To pursue this issue, we construct three proxies for anticipation-changes in relative spreads, rating gaps

Contrary to our expectations, ... the impact of one agency's announcement is greater if the announcement confirms the other agency's rating or a previous rating announcement.

between the agencies, and other rating announcementsall of which measure conditions before the announcement. The first proxy measures the change in relative spread (in the direction of the anticipated change) over the sixty days preceding the event. Prior movements in the relative spread may reflect the market's incorporation of information used by the agency in making the announcement. The second proxy indicates the sign of the gap between the rating of the agency making the announcement and the other agency's rating. A $n$ announcement that brings one agency's rating into line with the other's may be expected by market participants. In our regressions, the rating gap equals 1 (0) if the announcement moves the two agencies' risk assessments closer together (further apart). The third proxy is an indicator variable that equals 1 if another rating announce- ment of the same sign had occurred during the previous sixty days. This proxy is motivated by considerable evidence that rating announcements tend to be positively correlated - that is, positive announcements are more likely to be followed by positive announcements than by negative announcements and vice versa. ${ }^{21}$

We use each of the anticipation proxies in turn as a fifth explanatory variable in a multiple regression that includes the four indicator variables for actual rating changes, positive events, M oody's decisions, or speculativegrade sovereigns. A final regression adds all three anticipation proxy variables simultaneously to the basic regression (Table 9, columns 2-5).

Our earlier results are robust to the addition of the proxy variables. Announcements by Moody's and announcements pertaining to speculative-grade sovereigns continue to have a larger impact than announcements by Standard and Poor's or announcements pertaining to investmentgrade sovereigns. (N ote, however, that the statistical significance of the differences between the effects of the different rating agencies declines below the 10 percent level in three of the four new specifications.)

Contrary to our expectations, however, the results reported in Table 9 suggest that market anticipation does not reduce significantly, if at all, the impact of a sovereign rating announcement. The estimated coefficient on the change in the relative spreads variable has the expected negative sign, but it is not statistically significant. Moreover, the estimated coefficients on both the rating gap and the other rating announcement indicators are unexpectedly positive and highly significant. According to these two measures, the impact of one agency's announcement is greater if the announcement confirms the other agency's rating or a previous rating announcement.

\section{CONCLUSION}

Sovereign credit ratings receive considerable attention in financial markets and the press. We find that the ordering of risks they imply is broadly consistent with macroeconomic fundamentals. Of the large number of criteria used by Moody's and Standard and Poor's in their assignment of sovereign ratings, six factors appear to play an important 
role in determining a country's rating: per capita income, GDP growth, inflation, external debt, level of economic development, and default history. We do not find any systematic relationship between ratings and either fiscal or current deficits, perhaps because of the endogeneity of fiscal policy and international capital flows.

Our analysis also shows that sovereign ratings effectively summarize and supplement the information contained in macroeconomic indicators and are therefore strongly correlated with market-determined credit spreads. M ost of the correlation appears to reflect similar interpretations of publicly available information by the rating agencies and by market participants. Nevertheless, we find evidence that the rating agencies' opinions independently affect market spreads. Event study analysis broadly confirms this qualitative conclusion: it shows that the announcements of changes in the agencies' sovereign risk opinions are followed by bond yield movements in the expected direction that are statistically significant.
Although our event study results largely corroborate the findings of corporate sector studies, a few of our observations are surprising and invite further investigation. Our finding that the impact of rating announcements on spreads is much stronger for below-investment-grade than for investment-grade sovereigns is one puzzle. A nother surprising result is that rating announcements that are more fully anticipated, at least by our proxy measures, have, if anything, a larger impact than those that are less anticipated.

In sum, although the agencies' ratings have a largely predictable component, they also appear to provide the market with information about non-investment-grade sovereigns that goes beyond that available in public data. The difficulty in measuring sovereign risk, especially for below-investment-grade borrowers, is well known. Despite this difficulty - and perhaps because of it - sovereign credit ratings appear to be valued by the market in pricing issues. 


\section{ENDNOTES}

1. Although many studies have attempted to quantify the determinants of corporate and municipal bond ratings (see, for example, Ederington and Y awitz 1987; Moon and Stotsky 1993), our study is the first to quantify the determinants of the sovereign ratings assigned by Moody's and Standard and Poor's. Earlier researchers in the area of sovereign risk eval uated other measures of risk or presented a qualitative assessment of sovereign credit ratings. For example, Feder and Uy (1985) and Lee (1993) analyzed ordinal rankings of sovereign risk based on a poll of international bankers reported semiannually in Institutional Investor. Taylor (1995) discussed the importance of some of the same variables we examine, but he did not attempt to measure their individual and collective explanatory power.

2. Cantor and Packer (1995) providea broad overview of the history and uses of sovereign ratings and the frequency of disagreement between M oody's and Standard and Poor's.

3. These variables al so correspond closely to the determinants of default cited in the large academic literature on sovereign credit risk. See, for example, Saini and Bates (1984) and McFadden et al. (1985). This literature, focused largely on developing countries, estimates the importance of select variables in determining the probability that sovereign bank loans will default within one year. W e do not, of course, anal yze every variable consi dered in this literature. International reserves, a good indicator of short-term distress for developing economies, are unlikely to be helpful in explaining sovereign ratings, which measure default risk over a multiyear horizon for both devel oped and developing economies. W e therefore do not consider this variable in our analysis.

4. Because of data limitations, we use central government debt as our measure of fiscal bal ance, al though a more sati ffactory measure would be the consolidated deficits of the federal, state, local, and quasi-public sectors.

5. Debtors undoubtedly care about a country's total debt burden, not just its foreign currency debts. N onetheless, Moody's stresses that foreign currency obligations are generally given greater weight than total external liabilities in their sovereign ratings (M oody's 1991, p. 168).

Other measures of debt burden are also likely to be important, but they are not available for both devel oped and developing countries. T wo such variables are net foreign assets and debt-servicing costs, both of which can be measured in domestic and foreign currencies. Although we do not measure these two factors directly, they are correlated with variables we do measure - net foreign assets represent the accumulation of past current account surpluses, and foreign currency debt service is roughly proportional to foreign currency debt. The maturity of external liabilities is another important debt-related variable of interest, but it is not generally available for most countries
6. Countries with higher levels of development may also be less inclined to default on their foreign obligations because their economies are often substantially integrated with the world economy. As a result, devel oped economies are particularly vulnerable to the legal rights of creditors to disrupt trade or seize assets abroad. According to one strand of the theoretical literature on sovereign debt, the possibility of recourse to direct sanctionsis a necessary condition for sovereign lending (Bulow and Rogoff 1989).

7. Although this estimation technique suffers from the limitation that ratings are treated as cardinal variables, it is the only feasible approach given that we have just forty-nine jointly rated sovereigns and sixteen potential rating categories. W e found that the simple linear specification of the rating variable worked considerably better than nonlinear alternatives such as logarithmic or exponential functions. W e also tried unsuccessfully to estimate the relationships with ordered probit techniques, relying only on the ordinal properties of credit ratings. Because of the large number of rating categories and the relatively few sovereign rating assignments, our attempts to implement this approach were hindered by a failure of the maximum likelihood estimates to converge. In a similar study of corporate ratings, Ederington (1985) suggests that with larger sample sizes, inferences drawn from ordered probits are likely to be similar to, and perhaps slightly more accurate than, those drawn from least squares regressions. In contrast, in their study of corporate bond ratings, K aplan and U rwitz (1979) argue that linear least squares estimators perform better out of sample than those estimators derived from ordered probits.

8. These results were confirmed by ordered-probit regressions for rating differences. Although not reported here, the results of the probit regressions are available from the authors on request.

9. The relationship between ratings and yields is nonlinear; hence, we report our preferred specification of the natural logarithm of yields against ratings. This specification eliminates heteroskedasticity in the residuals as measured against rating levels.

10. Specifically, weincluded ratings from one agency at a time or sel ected either the higher or thelower of thetwo ratings for each country. W eal so tried adding two dummy variables to the average rating regressor: one that indicated whether or not the two agencies disagreed and, separately, one that indicated the identity of the agency with the higher rating.

11. This conclusion holds whether or not the sovereign is investment grade: separate regressions for investment-grade and speculative-grade subsamples look very similar to the full-sample regressions.

12. Because bond data are less readily available, event studies on stock 


\section{EN DN OTES (Continued)}

prices dominate the corporate rating literature. The event studies using bond data that precede $\mathrm{H}$ and, $\mathrm{H}$ olthausen, and Leftwich (1992) focus solely on monthly observations and conclude that bond prices are not affected by rating changes (W einstein 1977; Pinches and Singleton 1978; W akeman 1984; Ederington and Y awitz 1987). A more recent study by $\mathrm{H}$ ite and $\mathrm{W}$ arga (1996) al so uses monthly bond price data, but finds a significant announcement effect for downgraded firms.

13. W e obtained the bond yield data by searching the daily time series data on Euro, Y ankee, Global, and Brady bonds reported by Bloomberg L.P. and J.P. M organ and made available to us by J.P. M organ. For our event study, we used Bloomberg data for fifteen countries (A rgentina, A ustralia, Belgium, Brazil, Canada, Colombia, Denmark, Finland, I reland, Italy, M alaysia, N ew Zeal and, Sweden, Thailand, and Turkey) and fifty-seven rating announcements. W euse J.P. M organ data for seven countries (Argentina, Brazil, Colombia, Hungary, the Philippines, Turkey, and $V$ enezuela) and twenty-three rating announcements.

14. Standard and Poor's al ways indi cates whether a sovereign has a positive, negative, or stable outlook, and many of its rating announcements report a change in this outlook alone. The agency also occasionally places a sovereign on review for probable upgrade or downgrade. M oody's does not indicate an outl ook per se; however, it frequently places sovereigns on its watchlist for upgrades and downgrades.

15. Compare a 0.5 daily percentage point change during the announcement window for negativeannouncements with an average daily change of 0.1 for the preceding twenty-nine days. Similarly, compare a 0.7 daily percentage point changeduring the announcement window for positiveannouncements with an average daily change of 0.1 for the preceding period.

16. In the calculation of statistical significance, we control for potential heteroskedasticity with a procedure used by Mikkelson and Partch (1986) and Billet, Garfinkel, and O'N eal (1995). For each group of announcements, we cal culate weighted (standardized) means in which the weights equal the inverse of the standard deviation of the relevant daily changes in the logged relative bond spread calculated during the ninety-day period ending ten days before the announcement day. The Z-statistic for significanceis the standardized mean times the square root of the number of announcements.

17. To be consistent with the log-linear relationship between ratings and spreads depicted in Chart 1, we report mean and median changes to the log of the relative spread, although the results are not particularly sensitive to this aspect of the specification.

18. By contrast, most studies using stock market data find a significant price reaction to downgrades but not to upgrades (Goh and Ederington 1993).

19. Because the average absolute errors of the regression are larger when ratings are lower, we employ weighted least squares to control for this source of heteroskedasticity.

20. H and, Holthausen, and Leftwich (1992) find that Standard and Poor's announcements that corporate ratings are under review have significant market impact only when announcements classified by the authors as "expected" are excluded from the sample.

21. Of the 109 sovereign rating announcements between 1987 and 1994 that were followed by a rating change, 86 were foll owed by a change in the same direction. (Similarly, Altman and K ao [1991] have shown that corporate rating changes are often followed by further changes in the same direction.) Of the 79 rating announcements in our sample, 36 were preceded by a rating gap in the implied direction of the announcement. In 20 cases, other rating announcements in the same direction had been made in the preceding sixty days.

A Itman, Edward, and D uen L i Kao. 1991. "CorporateB ond R ating D rift: 


\section{REFEREN CES}

An Examination of Rating Agency Credit Quality Changes Over Time." N ew Y ork U niversity-Sal omon Brothers W orking Paper S91-40.

Billet, M atthew. 1996. "Targeting Capital Structure: The Relationship Between Risky Debt and the Firm's Likelihood of Being Acquired." JOURNAL OF BUSINESS. Forthcoming.

Billet, Matthew, J on G arfinke, and Edward O'N eal. 1995. "Insured Deposits, Market Discipline, and the Price of Risk in Banking." Federal Deposit Insurance Corporation, manuscript.

B ul ow, I er emy, and Kenneth R ogoff. 1989. "Sovereign D ebt: Is to Forgive to Forget?" American ECON OMIC RevieW 79, no. 1: 43-50.

Cantor, Richard, and Frank Packer. 1994. "The Credit Rating Industry." Federal Reserve Bank of $\mathrm{N}$ ew Y ork QuARTERLY ReVIEW 19, no. 2 (winter): 1-26.

- - - . 1995. "Sovereign Credit Ratings." Federal Reserve Bank of $\mathrm{N}$ ew York CURRENT ISSUES IN ECONOMICS ANd FInANCE 1, no. 3 (June).

Eaton, J onathan. 1996. "Sovereign Debt, Repudiation, and Credit Terms." InTERnATIONAL J OURn AL OF FINANCE AND ECON OMICS 1, no. 1 (J anuary): 25-36.

Ederington, Louis. 1985. "Classification Models and Bond Ratings." FINAN CIAL ReVIEW 4, no. 20 (N ovember): 237-62.

Ederington, Louis, and J ess Y awitz. 1987. "The Bond Rating Process." In Edward Altman, ed., HANDBOOK OF FINANCIAL MARKETS. N eW Y ork: J ohn W iley \& Sons: 23-57.

Ederington, Louis, Jess Y awitz, and B rian Roberts. 1987. "The Information Content of Bond Ratings." J OURnal OF FInANCIAL ReSEARCH 10, no. 3 (fall): 211-26.

Feder, G., and L. Uy. 1985. "The Determinants of International Creditworthiness and Their Implications." J OURnal OF POLICY MODELING 7, no. 1: 133-56.

$G$ oh, J eremy, and Louis Ederington. 1993. "Is a Bond Rating Downgrade Bad N ews, Good N ews, or N o N ews for Stockholders?" J OURNAL OF FINANCE 48, no. 5: 2001-8.
H and, J ohn, R obert H olthausen, and Richard Leftwich. 1992. "The Effect of Bond Rating Agency Announcements on Bond and Stock Prices." J OURNAL OF FINANCE 47, no. 2: 733-52.

Hite, Gailen, and Arthur W arga. 1996. "The Effect of Bond Rating Changes on Bond Price Performance." U npublished paper.

H orrigan, J. 1966. "The Determination of Long-Term Credit Standing with Financial Ratios." EM PIRICAL R ESEARCH IN ACCOUNTIN G 1966, J OURNAL OF ACCOUNTING RESEARCH 4 (supplement): 44-62.

Kaplan, R obert, and G abriel U rwitz. 1979. "Statistical M odel s of Bond Ratings: A M ethodological Inquiry." J OURNAL OF BUSINESS 52, no. 2: 231-61.

Lamy, Robert, and G. Rodney Thompson. 1988. "Risk Premia and the Pricing of Primary Issue Bonds." JOURnal OF BANKING AND FINANCE 12, no. 4: 585-601.

Lee, Suk H un. 1993. "A re the Credit Ratings A ssigned by Bankers Based on the Willingness of LDC Borrowers to Repay?" JOURNAL OF DeVELOPMENT ECON OMICS 40: 349-59.

$M$ cF adden, D anie, Richard Eckaus, $G$ ershon Feder, Vassilis $H$ ajivassiliou, and Stephen O'Connell. 1985. "Is There Life After Debt? An Econometric Analysis of the Creditworthiness of Developing Countries." In Gordon Smith and John Cuddington, eds., international Debt and the Developing Countries. W ashington, D.C.: W orld Bank.

M ikkeson, W., and M. Partch. 1986. "Valuation Effects of Security Offerings and the Issuance Process." JOURnal OF FInANCIAL ECON OMICS 15, no. 1/2: 31-60.

Moody's Investors Service. 1991. GLOBAL AnALYSIS. London: IFR Publishing.

- - . 1995. Sovereign Supranationals Credit Opinions, September.

M oon, C.G ., and J.G. Stotsky. 1993. "Testing the D ifferences between the Determinants of M oody's and Standard and Poor's R atings." J OU RNAL OF APPLIED ECON OMETRICS 8, no. 1: 51-69.

Ozler, Sule. 1991. "Evolution of Credit Terms: An Empirical Examination of Commercial Bank Lending to Devel oping Countries." J OURN AL OF DeVelopment ECON OMics 38: 79-97. 


\section{RefEREN CES (C ontinued)}

Pinches, G ., and J. Singleton. 1978. "The Adjustment of Stock Prices to Bond Rating Changes." J OURn AL OF FINAN CE 33, no. 1: 29-44.

Saini, K., and P. B ates. 1984. "A Survey of the Quantitative A pproaches to Country Risk Analysis." J OURNAL OF BANKING AND FINAN CE 8, no. 2: 341-56.

Standard and Poor's. 1994. "Sovereign Rating Criteria." EMERGING MARKETS, October: 124-7.

T aylor, J oseph. 1995. "Analyzing the Credit and Sovereign Risks of N onU.S. Bonds." In Ashwinpaul C. Sondhi, ed., CREDIT AnALYSIS OF Nontraditional DebT SeCurities. New York: Association for Investment R esearch, pp. 72-82.
W akeman, L. 1984. "The Real Function of Bond Rating Agencies." In Michael Jensen and Clifford Smith, eds., THE MODERN THEORY OF CORPorate FInANCE. N ew Y ork: McGraw-Hill.

W einstein, M . 1977. "The Effect of a R ating Change A nnouncement on Bond Price." J OURN AL OF FIN AN CIAL ECON OMICS 5, no. 3: 329-50.

The views expressed in this article are those of the authors and do not necessarily reflect the position of the Federal Reserve Bank of New York or the Federal Reserve System. The Federal Reserve Bank of New York provides no warranty, express or implied, as to the accuracy, timeliness, completeness, merchantability, or fitness for any particular purpose of any information contained in documents produced and provided by the Federal Reserve Bank of New York in any form or manner whatsoever. 
